\title{
Perspectives for the Development of the Collaboration Relations in the Association Forms for Association Forms in the Galaţi County
}

\author{
Andrei-Mirel FLOREA ${ }^{1}$ \\ Riana RADU ${ }^{2}$ \\ Adriana MOCANU PUSTIANU ${ }^{3}$ \\ Silvius STANCIU ${ }^{4}$
}

\begin{abstract}
Organizing a viable irrigation system in the context of climate change at the level of Romanian agriculture is a priority. Currently, only $12 \%$ of the total agricultural area is irrigated. In order to benefit from irrigation, Romanian farmers must be members of the Organization of the Irrigation Water Users (OUAI), assigned to the area in which they own land or conclude seasonal contracts. A survey addressed to the OUAI in Galati County attempted to identify the relations between the members that can lead to the association not only for irrigation, but also for agricultural activities.

An analysis of the data obtained from the survey was carried out, using the „fuzzy set comparative qualitative analysis" ( $\left.f_{S} Q C A\right)$ method, in the context of land fragmentation, in conjunction with supporting national and European programs for the association and development of the irrigation infrastructure.

The results of the study are important because it reflects the main issues highlighted bv the farmers in the analvzed area regarding the association.
\end{abstract}

Keywords: agriculture, association, OUAI, fsQCA, collaboration forms

JEL classification: M20, M41

DOI: $10.24818 /$ RMCI.2018.5.497

\section{Introduction}

Global warming, as shown by The World Bank in its reports, can have disastrous effects on the agricultural production and on crops in general. A major impact of the climate changes on agriculture will occur by reducing the annual water

1 Andrei-Mirel Florea, „Dunarea de Jos” University of Galati, Galati, Romania, PhD. Student, +40754408153, floreaandreim@yahoo.com

2 Riana Radu, „Dunarea de Jos” University of Galati, Galati, Romania, +40740091258, raduriana@gmail.com

3 Adriana Pustianu, „Dunarea de Jos” University of Galati, Galati, Romania, PhD. Student, adriana.pustianu@yahoo.com

${ }^{4}$ Silvius Stanciu, „Dunarea de Jos” University of Galati, Galati, Romania, +40722244407, silvius.stanciu@ugal.ro 
availability in many areas of Europe as a result of rainfall reduction mainly in southern areas and in some parts of Central Europe. Many countries in the European Union have practiced irrigation for hundreds of years, this being part of the agricultural tradition of the area. However, this sector will need innovative irrigation techniques, given the current climate change conditions. In many regions, increasing the irrigated area is necessary in order to ensure a constant production. There is no doubt that agriculture must continue to make significant efforts to use the water more efficiently and that irrigation plans need to be carefully elaborated, requiring an assessment of their impact in the smallest detail. Ensuring an efficient irrigation system in the conditions of the climatic changes manifested in the last 50 years is also a necessity for the Romanian agriculture (MADR, 2016).

The Romanian agricultural sector did not enjoy a favourable perspective after 1990. The agricultural activity was inefficient or insufficiently effective and until recently, it had been avoided by investors (European Commission, 2015)

Drought is among the most damaging natural hazards, with a severe impact on communities and water-dependent sectors (Sönmez et al., 2005). The complexity of the impact is mainly caused by the water dependence of a large number of sectors producing goods and services. (Wilhite et al., 2007)

The competitiveness of the agricultural sector is strongly influenced by the underdevelopment of the irrigation infrastructure, which leads to the emergence of strong economic effects on farms (Maracine et al., 2009). The establishment of the Organization of the Irrigation Water Users (OUAI) was one of the main steps in order to achieve collaboration for the development of the association and for increasing the productivity, by ensuring crop irrigation (MADR, 2011). According to Law 138/2004 on the regulation of land improvement activities, OUAI are legal entities of public utility without patrimonial purpose, which are made up of landowners in the vicinity of the irrigation systems which joined this form of association in order to benefit from irrigation facilities, drainage and withering. Thus, the association to OUAI is a mandatory condition in order to benefit from water for irrigation. 66 Land Improvement Organizations, of which 56 OUAI, 5 Federations of Land Improvement Organizations (FOIF) and 5 Drainage and Withering Organizations (ODD) are registered in Galati County at the level of 2017.

The association is beneficial to agriculture because it combines the capital, the labour force, the suppliers and the customers, so by association, the farmers are able to get a larger portfolio of suppliers and customers. The size of their business is expanding and, implicitly, they have more power to negotiate. These advantages are related to a greater adaptability to the market and, obviously, the knowledge of the members of the association can be improved because they «borrow» experience from others (Argote \& Ingram, 2000).

The starting point in the present study is represented by the exchange of experience and knowledge among OUAI members and if farmers choose to join a form of association and agricultural activities from this association. Using the Fuzzy set qualitative comparative analysis (fsQCA) method, it was attempted to demonstrate the "association leads to association" statement. 


\section{Material and methods}

The information needed to conduct the study was obtained by consulting MADR databases and Scopus and Google Academic scientific databases. An interview based on a survey was conducted in order to collect the data. This survey was distributed to the OUAI members working in the field of agriculture at the level of Galaţi County, Romania.

fsQCA was used for data processing, because this method is indicated to apply to small data samples, but also because it generates a combined analysis of causal conditions, which cannot be obtained by individual analysis of each element (Ragin, 2008).

The sample under study consists in 16 members, which are part of several OUAIs in the region concerned. Due to the fact that the chosen method does not limit the size of the sample and the respondents are not part of the same organization, we consider that the study can give us a general overview of the aspect proposed for demonstration, at the level of Galati County.

In order to apply the above mentioned method, the survey was divided into three major sections. The first section is represented by general information about the respondents: age, occupation, level of occupation, the size of the agricultural holding they are managing.

The second section of the survey included 2 questions that determined whether the respondents, although landowners, are engaged or not in agricultural activities and whether they are members of a different form of association than OUAI.

The last part of the survey contains three questions whose answers represented the basic information for the analysis using the fsQCA method. These last questions in the survey were designed so that respondents had as response variants Likert scale with 5 values, out of which 1 represents "Definitely not" and 5 "Definitely yes".

After collecting and centralizing the surveys, it followed the process of calibrating the values obtained in data that were recognized by the fsQCA software used, respectively fsQCA 3.0.

Each factor was replaced in the calibration process with values between 0 and 1 (Ragin, 2000), depending on the responses collected from the interviewees.

The scale used for calibration is shown in Table 1.

Table 1. Calibration of scales

\begin{tabular}{|l|l|}
\hline Scale point & Fuzzy-set value \\
\hline Strongly influenced (Definitely yes) & 1 \\
\hline Significant influence & 0.75 \\
\hline Influenced & 0.5 \\
\hline Insignificant influence & 0.25 \\
\hline Unaffected (Definitely no) & 0 \\
\hline
\end{tabular}

(adapted from Ragin, 2000) 
Table 2. Calibration of all variables

\begin{tabular}{|c|c|c|c|}
\hline Case & $\begin{array}{c}\text { association_to_ } \\
\text { association } \\
\text { (condition 1) }\end{array}$ & $\begin{array}{c}\text { if_necessary } \\
\text { you_would_associate } \\
\text { (condition 2) }\end{array}$ & $\begin{array}{c}\text { association_is_the_ } \\
\text { solution } \\
\text { (outcome) }\end{array}$ \\
\hline C1 & 0.5 & 1 & 1 \\
\hline C2 & 0.5 & 0.75 & 0.75 \\
\hline C3 & 0.5 & 0.75 & 0.75 \\
\hline C4 & 0.75 & 0.75 & 1 \\
\hline C5 & 0.25 & 0.5 & 0.5 \\
\hline C6 & 1 & 0.75 & 1 \\
\hline C7 & 0.5 & 0.75 & 0.75 \\
\hline C8 & 0.25 & 0.25 & 0.25 \\
\hline C9 & 0.75 & 0.75 & 0.75 \\
\hline C10 & 0.5 & 1 & 0.75 \\
\hline C11 & 0.5 & 0.75 & 1 \\
\hline C12 & 0.75 & 0.5 & 1 \\
\hline C13 & 0.75 & 1 & 0.75 \\
\hline C14 & 0.75 & 0.75 & 1 \\
\hline C15 & 0.5 & 1 & 0.5 \\
\hline C16 & 0.25 & 0.25 & \\
\hline
\end{tabular}

\section{Findings}

In the first step of the analysis, the collected data was verified, to determine whether they meet the consistency and coverage conditions necessary to demonstrate the requisite that the association leads to association. The consistency indicates the extent to which one of the causal conditions is a subgroup of the result (Seate et al., 2015). The degree of consistency varies from 0 to 1 , where 0 denotes that the causal combination or the factor independently is not a subset of the result. The consistency degree 1 reflects the fact that the individual factor or the causal combination is a subset of the result (Ragin, 2000).

One of the possibilities offered by the program for the presentation of consistency is represented by the distribution of individual cases through the XY Plot graphs.

In this context, the consistency evaluates the extent to which the instances of an outcome agree with displaying the causal condition deemed necessary, while coverage assesses the relevance of the causal condition - the degree to which the cases that generate the conditions are associated with those that produce the outcome.

In the plot of affiliation to the outcome $(\mathrm{Y})$ against affiliation to a causal condition or in a combination of causal conditions (X), the consistency is defined as the proportion of cases on or above the main diagonal of the graph.

A case on or above the main diagonal is consistent because the affiliation to the causal condition is less than or equal to its capacity as member in the outcome. A 
case under the main diagonal is inconsistent, since its affiliation to the causal condition is greater than its capacity as member in the outcome. (Ragin, 2000).

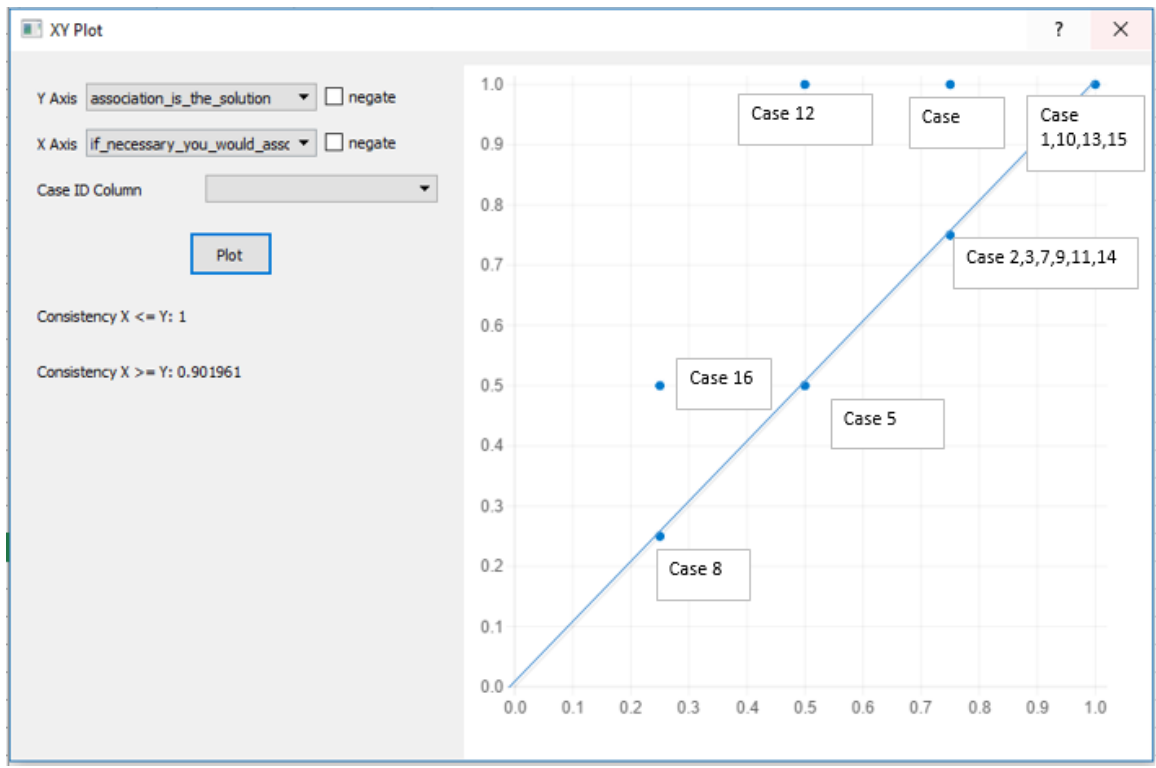

Figure 1. Distribution of cases within XY Plot graph

Following to running Quine-McCluskey algorithm, it was generated the complex solution of the model which is presented in Table 4 - Complex solution:

Table 4. Complex solution

\begin{tabular}{lllc}
\hline Complex solution & $\begin{array}{l}\text { Raw } \\
\text { coverage }\end{array}$ & $\begin{array}{l}\text { Unique } \\
\text { coverage }\end{array}$ & Consistency \\
\hline $\begin{array}{l}\text { association_to_association*_if_necessary_you_would_associate } \\
\text { association_to_association*if_necessary_you_would_associate }\end{array}$ & $\begin{array}{l}0.254902 \\
0.666667\end{array}$ & 0.0392157 & 0.8125 \\
& & 0.45098 & 1 \\
$\begin{array}{l}\text { solution coverage: } 0.705882 \\
\text { solution consistency: } 0.923077\end{array}$ & & \\
\hline
\end{tabular}

Single coverage refers to the proportion of cases that show the outcome that a causal input is covering in a unique way. Raw coverage refers to the proportion of cases in which the outcome is explained by causal entry, regardless of the conceptual overlapping with other causal inputs (Ragin, 2000).

The algorithm generates two possible solutions. The first solution tests the hypothesis that association does not lead to association, corroborated with the hypothesis of a diminished association requirement, solution which is not validated by the obtained coverage results and consistency as shown in Table 5 . 
Table 5. Analysis of Necessary Conditions

\begin{tabular}{|c|c|c|}
\hline \multicolumn{3}{|c|}{ Outcome variable: association_is_the_solution(outcome) } \\
\hline Conditions tested 1: & Consistenc & Coverage \\
\hline $\begin{array}{l}\text { association_to_association(condition1)+ } \\
\sim \text { if_necessary you_would_associate }\end{array}$ & 0.509804 & 0.866667 \\
\hline Conditions tested 2: & Consistency & Coverage \\
\hline $\begin{array}{l}\text { association_to_association(condition } 1)+ \\
\text { if_necessaryyou_would_associate }\end{array}$ & 0.941176 & 1.000000 \\
\hline $\begin{array}{l}\text { Conditions tested 3: } \\
\text { association_to_association(condition } 1 \text { ) }\end{array}$ & $\begin{array}{c}\text { Consistency } \\
0.705882\end{array}$ & $\begin{array}{l}\text { Coverage } \\
1.000000\end{array}$ \\
\hline
\end{tabular}

The second solution presented is the combination of the two causal conditions. This shows that participation to an associative form, combined with an understanding of the importance of association for Romanian agriculture, leads to the acceptance of associative forms as a solution to rejuvenate the agriculture. The fact that the need for association is quantified and known implies its acceptance.

The members of the chosen sample, although they are already part of a form of association in the field of irrigation, do not significantly influence their possible association also in the field of agriculture, as it influences in this sense the awareness of the necessity of association.

In the analyzed cases, the concept of "association leads to association" is surpassed by the concept of "if necessary, then we associate" due to the age of the irrigation infrastructure and to the lack of allocation of rehabilitation funds. Through the European funds available under measure 4.3, there is the possibility to obtain financing for OUAIs which submit projects for rehabilitation.

\section{Conclusions}

The implementation of the associative forms represents a solution for the rejuvenation of the Romanian agriculture. In the present research, we have demonstrated that if the farmers will understand the need for association, this will determine the acceptance of this solution. However, for such an association development action to be valid by presenting the benefits and the need for association, it is important to clarify the legislative aspects related to the association (Mazzarol et al., 2013), to provide real tax incentives to draw in the farmers and to continue to invest in agriculture.

The Governmental policies and the support granted for the creation and development of cooperatives are essential, not only for their sustainability, but also for the decision to create. Although the implementation of the association in the Romanian agriculture is an option accepted by the analysed sample, they consider that only acceptance is not sufficient. 
We believe it is advisable to engage the government through intensive campaigning to promote the association, after the fiscal and investment aspects on the association are resolved.

Carrying out a promotion campaign without making investments or providing real funding opportunities would not lead to the expected result.

The irrigation sector faces the same investment difficulties as the agricultural sector, so that the membership in OUAI is not likely to provide a favourable picture of the associated forms.

\section{References}

Banca Mondiala, (2013), Raportul anual al Bancii Mondiale 2014, disponibil la https://openknowledge.worldbank. org/handle/10986/16238

European Commission, 2015. Factsheet on 2014-2020 Rural Development Programme for Romania. http://ec.europa.eu/agriculture/ ruraldevelopment2014-2020/country-files/ro/factsheeten.pdf.

European Commission, 2013. Guide to Social Innovation. DG Regional and Urban Policy, Luxemburg.

MADR, (2011), Strategia Investiţiilor în Sectorul Irigaţiilor, Fidman Merkat. Bucureşti disponibil la http://www.madr.ro/docs/minister/ programulnational-reabilitare-irigatii-.pdf

MADR, (2016),Programul Naţional de Reabilitare a Infrastructurii Principale de Irigaţii din România, disponibil la http://www.madr.ro /docs/ minister/programul-national-reabilitare-irigatii-.pdf

Maracine N., Maracineanu F., Constantin E., Cimpeanu S. (2009). Present and Future in the Romanian Irrigation Facilities Operation Management. Bulletin UASVM Horticulture, 66(2)/2009, Print ISSN 1843-5254; Electronic ISSN 1843-5394

Mazzarol, T., Limnios, E., Reboud, S., 2013. Co-operatives as a strategic network of small firms: case studies from Australian and French co-operatives. Journal of Co-operative Organization and Management 1 (2), 27e40.

Ragin, C.C. (2008). Redesigning social inquiry: Fuzzy sets and beyond. Chicago: University of Chicago Press.

SeateA., A., Joyce N., Harwood J., Arroyo A., (2015), Necessary and Sufficient Conditions for Positive Intergroup Contact: A Fuzzy Set Qualitative Comparative Analysis Approach to Understanding Intergroup Attitudes, Communication Quarterly, 63:2, 135-155, DOI: 10.1080/01463373. 2015.1012215

Sönmez F.K., Kömüscü A.Ü., Erkan A., Turgu E., An analysis of spatial and temporal dimension of drought vulnerability in Turkey using the standardized precipitation index, Nat. Hazards 35 (2) (2005) 243-264

Wilhite D.A., Svoboda M.D., Hayes M.J., Understanding the complex impacts of drought: a key to enhancing drought mitigation and preparedness, Water Resour. Manag. 21 (5) (2007) 763-774. 